\title{
Sexuality and assessment of physical and psychological symptoms of older adults in outpatient care
}

\author{
Sexualidade e avaliação de sintomas físicos e psicológicos de idosos em assistência ambulatorial \\ Sexualidad y valoración de la sintomatología física y psicológica del anciano en consulta externa
}

Natalia Coelho Marques da Silva'
ORCID: 0000-0002-5713-8196

Luana Baldin Storti'

ORCID: 0000-0002-5428-2520

Gabriella Santos Lima'

ORCID: 0000-0001-8657-4002

Renata Karina Reis

ORCID: 0000-0002-0681-4721

Thaís França de Araújo" ORCID: 0000-0001-5244-9051

Luciana Kusumota'

ORCID: 0000-0001-9290-3722

'Universidade de São Paulo. Ribeirão Preto, São Paulo, Brazil.

"Universidade Federal de Uberlândia. Uberlândia,

Minas Gerais, Brazil.

How to cite this article:

Silva NCM, Storti LB, Lima GS, Reis RK, Araújo TF,

Kusumota L. Sexuality and assessment of physical and psychological symptoms of older adults in outpatient care. Rev Bras Enferm. 2021;74(Suppl 2):e20200998. https://doi.org/10.1590/0034-7167-2020-0998

\section{Corresponding author:}

Natalia Coelho Marques da Silva

E-mail: nacoelhoms@gmail.com

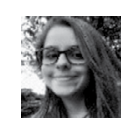

EDITOR IN CHIEF: Antonio José de Almeida Filho ASSOCIATE EDITOR: Fátima Helena Espírito Santo

Submission: 10-30-2020

Approval: 01-08-2021

\section{ABSTRACT}

Objective: to analyze the relationship between affective and sexual experiences and the intensity of physical and psychological symptoms of older adults. Methods: observational, crosssectional and analytical study, guided by the STROBE tool, carried out in a geriatric outpatient clinic. Sociodemographic and health questionnaire, Affective and Sexual Experiences Scale for Elderly, Edmonton Symptom Assessment Scale were used. Descriptive statistical analysis and Spearman correlation were performed. Results: forty-five older adults participated, with a mean age of 73.8 years; most $(91.1 \%)$ were married. The highest averages of symptom intensity were pain (4.9), anxiety (4.8), drowsiness (4.5), and a feeling of well-being (4.5). There was a negative correlation between sadness and the dimensions of sexual activity and affective relationships $\left(r_{s}=-0.365 ; p=0.014\right.$ and $\left.r_{s}=-0.386 ; p=0.009\right)$ and between anxiety and sexual activity $\left(r_{s}=-0.308\right.$; $\mathrm{p}=0.040$ ). Conclusion: as sadness increases, affective and sexual experiences are less. The greater the anxiety intensity, the lower the sexual experiences.

Descriptors: Sexuality; Symptom Assessment; Aged; Ambulatory Care; Geriatric Nursing.

\section{RESUMO}

Objetivo: analisar a relação entre as vivências afetivas e sexuais e a intensidade de sintomas físicos e psicológicos dos idosos. Métodos: estudo observacional, transversal e analítico, norteado pela ferramenta STROBE, realizado em um ambulatório de geriatria. Utilizou-se: questionário sociodemográfico e de saúde; Escala de Vivências Afetivas e Sexuais do Idoso; Escala de Sintomas de Edmonton. Realizou-se análise estatística descritiva e correlação de Spearman. Resultados: participaram 45 idosos com média de idade 73,8 anos e a maioria $(91,1 \%)$ casada. As maiores médias de intensidade de sintomas foram dor $(4,9)$, ansiedade $(4,8)$, sonolência $(4,5)$ e sensação de bem-estar $(4,5)$. Houve correlação negativa entre tristeza e as dimensões ato sexual e relações afetivas $\left(r_{s}=-0,365 ; p=0,014\right.$ e $\left.r_{s}=-0,386 ; p=0,009\right)$ e entre ansiedade e ato sexual $\left(r_{s}=-0,308 ; p=0,040\right)$. Conclusấo: à medida que aumenta a tristeza, são menores as vivências afetivas e sexuais. Quanto maior a intensidade de ansiedade, menores são as vivências sexuais.

Descritores: Sexualidade; Avaliação de Sintomas; Idoso; Assistência Ambulatorial; Enfermagem Geriátrica.

\section{RESUMEN}

Objetivo: analizar la relación entre las experiencias afectivas y sexuales y la intensidad de los síntomas físicos y psicológicos de las personas mayores. Métodos: estudio observacional, transversal y analítico, guiado por la herramienta STROBE, realizado en un ambulatorio geriátrico. Se utilizó: cuestionario sociodemográfico y de salud; Escala de Experiencias Afectivas y Sexuales del Adulto Mayor; Escala de síntomas de Edmonton. Se realizó análisis estadístico descriptivo y correlación de Spearman. Resultados: participaron 45 ancianos, con una edad media de 73,8 años y la mayoría $(91,1 \%)$ casados. Los mayores promedios de intensidad de los síntomas fueron dolor $(4,9)$, ansiedad $(4,8)$, somnolencia $(4,5)$ y sensación de bienestar $(4,5)$. Hubo una correlación negativa entre la tristeza y las dimensiones del acto sexual y las relaciones afectivas $(r=-0,365$; $\left.\mathrm{p}=0,014 \mathrm{y} \mathrm{r}_{\mathrm{s}}=-0,386 ; \mathrm{p}=0,009\right)$ y entre la ansiedad y el acto sexual $\left(\mathrm{r}_{\mathrm{s}}=-0,308 ; \mathrm{p}=0,040\right)$. Conclusión: a medida que aumenta la tristeza, las experiencias afectivas y sexuales son menores. Cuanto mayor es la intensidad de la ansiedad, menores son las experiencias sexuales.

Descriptores: Sexualidad; Evaluación de Síntomas; Anciano; Atención Ambulatoria; Enfermería Geriátrica. 


\section{INTRODUCTION}

Taboos, myths and stigmas are related to people's culture, religious and political influence. In the past, sexuality was not discussed, the dialogue between parents and children was restricted, few people attended school and religion exercised a great influence on the approach to sexuality, in which this theme was and still is scolded, as it is only associated with procreation and genitality. It is worth mentioning that, in the middle of the $21^{\text {st }}$ century, society has an evasive position when it comes to sexuality in old age ${ }^{(1)}$, despite the advances in discussions on this theme in academic, clinical, social and media contexts ${ }^{(2-3)}$.

It is noteworthy that the prejudice of sexual activity in old age is adopted because it is believed that the phase of experiencing sexuality is conditioned to the age of the youngest ${ }^{(4)}$. Another aspect considered by older adults refers to body beauty linked to youth and, due to advancing age, they do not feel attractive to have sex $x^{(5)}$. The feeling of femininity or not being attractive anymore due to the physical changes caused by aging, portrays the decline in sexual function, especially by female older adults ${ }^{(6)}$. Studies ${ }^{(5,7)}$ address the misconception that in climacteric and menopause sexuality is exhausted and this is related to the concept that attraction only occurs with the beauty of youth and physical vigor.

The judgment and vigilance that society maintains about older adults makes them feel inhibited to naturally express their sexual identity ${ }^{(8-10)}$. Thus, older adults can assimilate these reflexes as truth, leading to personal deprivation and the adoption of behavior according to social expectations ${ }^{(11)}$. It is worth mentioning that the education model of the ancestors united to the current one involves repressive rules and, even when older adults feel censored about their sexuality, the majority argues that their desires and desires still continue and that they want to experience them, even with the physiological changes occurred ${ }^{(4-6,10,12-13)}$.

In this context, it is important to note that sexuality is influenced by several factors, including biological, psychological, spiritual, cultural, religious, social, economic, political, legal and historical factors. In addition to pleasure and sexual activity, sexuality encompasses personal identity, sex, the roles that older adults are inserted in society, sexual orientation, affection, intimacy, romance, companionship, and relationships ${ }^{(14)}$.

A study developed with older adults showed the importance of sexual experiences and the positive correlation between sexuality and their quality of life through companionship and mutual love. The authors concluded that in old age there is friendship, love, affection, companionship, pleasure, and complicity. Thus, sexuality is not limited to sexual activity, there are other essential components that lead older adults to feel pleasure. They also emphasized the importance of sexual experiences for older adults, who have desires and believe that they can love, feel pleasure and be happy ${ }^{(15)}$.

Still, it is worth mentioning that, in addition to the biological changes inherent to the natural aging process, older adults may present morbidities that lead to the manifestation of signs and symptoms ${ }^{(16)}$, which can be physical and/or psychological, such as pain, fatigue, nausea, depression, anxiety, drowsiness, appetite, feeling of well-being, dyspnea, and sleepiness. It is believed that these symptoms may be related to the affective and sexual experiences of older adults.

In this sense, there are scientific gaps about sexuality in old age, especially that guide professional performance, who are often led by the stereotype that in old age sexuality is not experienced ${ }^{(17)}$. Moreover, this theme is rarely addressed and discussed in undergraduate courses in the health field, despite the growing number of scientific research and collaboration groups for advances in this theme ${ }^{(18)}$.

It is believed that research related to sexuality in old age is extremely important for health professionals to identify the affective and sexual experiences of older adults and start addressing the needs related to the theme in their care, when relevant. Thus, the research questions were elaborated: what are the affective and sexual experiences of older adults in outpatient care? Do the affective and sexual experiences of older adults relate to the intensity of their physical and psychological symptoms?

\section{OBJECTIVES}

To characterize older adults seen at a geriatric outpatient clinic of a tertiary general hospital in the countryside of São Paulo according to sociodemographic, health and affective and sexual experiences.

To analyze the relationship between affective and sexual experiences and the intensity of physical and psychological symptoms of older adults.

\section{METHODS}

\section{Ethical aspects}

According to Resolution 466/12 of the Brazilian National Health Council (Consellho Nacional de Saúde), this study was assessed and approved by the Research Ethics Committee of Escola de Enfermagem de Ribeirão Preto at Universidade de São Paulo and at Hospital das Clínicas of Faculdade de Medicina de Ribeirão Preto at Universidade de São Paulo.

\section{Study design, period, and place}

This is an observational, cross-sectional and analytical study, guided by the STROBE tool. It was carried out from September 2018 to April 2019 at the geriatric outpatient clinic of a tertiary general hospital in the countryside of São Paulo, on the day and time of service, i.e., on Tuesdays, from 1 p.m. to 6 p.m..

\section{Population or sample; inclusion and exclusion criteria}

The study population consisted of older adults seen at the outpatient clinic, with 224 older adults being approached. Older adults over 60 years of age, married or with a fixed partner were selected as a prerequisite for the application of the study instrument, which has preserved cognitive ability, assessed through the investigation of orientation in time, space and people were included. Using these criteria, 150 older adults were excluded (122 widowers, 20 singles and eight failed cognitive assessment); still, 
there were 24 refusals and five losses. It is noteworthy that the excluded participants with marital status (widowed and single), when asked, responded that they did not have a steady partner. Thus, the consecutive non-probabilistic sample consisted of 45 older adults.

\section{Study protocol}

Data collection was carried out through an interview, directed by the researcher herself, who approached older adults in the outpatient waiting room, when she identified herself, performed the necessary clarifications on the study, inviting them to participate. Then, she presented and discussed the Informed Consent Form (ICF). After the clarification and acquiescence of each participant, they were asked to sign on to ICF and a copy was given to participants. Thus, the interview started in the waiting room or in an office of the referred clinic, in order to guarantee privacy and avoid possible interruptions and noise.

For the interviews, an approach organized in four parts was used, described below: Part 1 - cognitive assessment was performed through assessment of participants' discriminatory, psychological and mental capacity in time and space with preestablished questions ${ }^{(19-20)}$ : what is your full name? What is your birth date? What day of the week are we on? What is the name of the place we are in at the moment? The data were verified using an identification document. Participants were excluded from the study when they did not answer at least three questions. Part 2 - adapted for older adults health and demographic questionnaire ${ }^{(21)}$, containing personal information (date of birth, sex, number of children, partner's sex), social profile (can read/ write, education, who lives with them, monthly income, type of income, religion, participation of social groups) and health condition (perception of health and health problems). Part 3 - Affective and Sexual Experiences Scale for Elderly (ASESE), which assesses the affective and sexual experiences of older adults, investigating the feelings, behaviors and attitudes of older adult towards themselves and the other (their partner). ASESE consists of 38 items distributed in three dimensions: sexual activity, affective relationships and physical and social adversities, which have shown to assume satisfactory statistical parameters in a scale validation study. It is a Likert-type scale, with five response options: never, rarely, sometimes, often, and always. The results are interpreted for each dimension, and in this study, the highest scores obtained were considered, reflecting greater affective and sexual experiences of older adults, as interpreted by the scale's author ${ }^{(22)}$. Part 4 - Edmonton Symptom Assessment Scale (ESAS-Br), which assesses the intensity of ten symptoms: pain, tiredness, nausea, sadness, anxiety, appetite, drowsiness, shortness of breath, well-being, and sleepiness. It was translated and validated for Brazil with patients in specific clinical situations of palliative care and advanced cancer ${ }^{(23-26)}$, being, to date, the first study to use the scale in a general sample of older adults. It is a visual numerical scale varying between zero and ten, with zero being the minimum intensity and ten being the maximum intensity. It is considered self-applicable or the interviewer may apply it ${ }^{(27)}$.

\section{Data analysis, and results}

For data processing, a data spreadsheet was created in the Microsoft Excel computer program, containing a dictionary (codebook) and two spreadsheets that were used for double entry validation (typing). After typing and validation, the data were analyzed using the Statistical Package for the Social Sciences software, version 20.0. For characterization of sociodemographic and health aspects as well as sexual and affective experiences and the intensity of physical and psychological symptoms of participants, a descriptive analysis of simple frequency and/or measures of central tendency (mean and median) and variability (standard deviation). Spearman's correlation $\left(r_{s}\right)$ was performed to verify the relationship between the variables sexual and affective experiences and the intensity of participants' physical and psychological symptoms. The level of significance adopted was 5\%.

\section{RESULTS}

Forty-five older adults participated in this study. The age varied between 60 and 89 years, with an average of 73.8 years $(S D=6.7)$. The average number of children was $3.3(\mathrm{SD}=1.9)$.

Regarding religion, most $(\mathrm{n}=33 ; 73.3 \%)$ reported being Catholic. As for education, 40 (88.9\%) older adults reported knowing how to read or write. The years of study ranged from one to 15 years, with an average of 6.3 years $(S D=4.3)$. Regarding the type of income, 31 (68.9\%) older adults mentioned having retirement. The average monthly income was $R \$ 1,855.40$ ( $S D=1404.1$ ).

As for the health status, 18 (40.0\%) older adults described their health as "reasonable", 41 (91.1\%) older adults reported having health problems, including high blood pressure, 19 (42.2\%) and diabetes, 14 (31.1\%). The number of health problems ranged between zero and six, with an average of $2.5(\mathrm{SD}=1.5)$.

Table 1 shows the characterization of older adults, according to sex, marital status and who they live with.

Table 2 shows the distribution of ESAS-Br physical and psychological symptoms according to the mean, median scores and standard deviation of symptom intensities.

Higher mean intensity scores are observed for symptoms of pain (4.9), anxiety (4.8), drowsiness (4.5), and a feeling of wellbeing (4.5).

Table 3 shows the distribution of ASESE dimensions according to the mean scores, standard deviation and amplitude.

As for the affective and sexual experiences of older adults, assessed through ASESE, there are higher averages for affective relationships (3.1) and sexual activity (2.3) dimensions.

Table 4 presents the list of correlation analyzes. There was a negative correlation between the ESAS-Br sadness symptom scores and the ASESE sexual activity and affective relationships dimensions $\left(r_{s}=-0.365 ; p=0.014\right.$ and $r_{s}=-0.386 ; p=0.009$, respectively), as well as between the scores of the anxiety symptom of ESAS-Br and the sexual activity dimension of ASESE $\left(r_{s}=-0.308\right.$; $p=0.040$ ). There was a positive correlation between the scores of the ESAS-Br shortness of breath symptom and the ASESE physical and social adversity dimension $\left(r_{s}=0.372 ; p=0.012\right)$. 
Table 1 - Distribution of older adults according to the variables sex, marital status and with whom they live, attended at a geriatric outpatient clinic, Ribeirão Preto, São Paulo, Brazil, 2019

\begin{tabular}{lcc}
\hline Variables & $\mathbf{n}$ & $\%$ \\
\hline Sex & & \\
$\quad$ Male & 21 & 46.7 \\
$\quad$ Female & 24 & 53.3 \\
Marital status & & \\
$\quad$ Married & 41 & 91.1 \\
Single & 1 & 2.2 \\
$\quad$ Divorced & 1 & 2.2 \\
Widowed & 1 & 2.2 \\
$\quad$ Living together & 1 & 2.2 \\
Living with & & \\
$\quad$ Alone & 2 & 4.4 \\
$\quad$ Spouse and child (ren) & 7 & 15.6 \\
Only with companion & 31 & 68.9 \\
$\quad$ Others* & 5 & 11.1 \\
Total & 45 & 100.0 \\
\hline
\end{tabular}

Note: *Others (lives with: partner and grandchildren; partner, children, son-in-law, daughter-in-law and grandchildren; partner and brothers; partner, children and mother-in-law).

Table 2 - Distribution of Edmonton Symptom Assessment Scale symptoms according to the comparison between means, medians, standard deviation, Ribeirão Preto, São Paulo, Brazil, 2019

\begin{tabular}{lccc}
\hline $\begin{array}{l}\text { Edmonton Symptom } \\
\text { Assessment Scale symptoms }\end{array}$ & $\begin{array}{c}\text { Mean } \\
\text { (SD*) }\end{array}$ & $\begin{array}{c}\text { Amplitude } \\
\text { (minimum - maximum) }\end{array}$ \\
\hline Pain & $4.9(3.4)$ & 0 & 10 \\
Anxiety & $4.8(3.8)$ & 0 & 10 \\
Drowsiness & $4.5(3.2)$ & 0 & 10 \\
Feeling of well-being & $4.5(3.5)$ & 0 & 10 \\
Tiredness & $4.4(3.1)$ & 0 & 9 \\
Sleepiness & $4.2(3.6)$ & 0 & 10 \\
Sadness & $3.8(3.9)$ & 0 & 10 \\
Appetite & $3.8(3.5)$ & 0 & 10 \\
Shortness of breath & $2.3(3.4)$ & 0 & 10 \\
Nausea & $1.6(2.7)$ & 0 & 10 \\
\hline
\end{tabular}

Note: ${ }^{*} \mathrm{SD}=$ standard deviation.

Table 3 - Distribution of Affective and Sexual Experiences Scale for Elderly dimensions according to the comparison between the means, Ribeirão Preto, São Paulo, Brazil, 2019

\begin{tabular}{lccc}
\hline $\begin{array}{l}\text { Affective and Sexual Experiences } \\
\text { Scale for Elderly dimensions }\end{array}$ & $\begin{array}{c}\text { Mean } \\
\text { (SD*) }\end{array}$ & $\begin{array}{c}\text { Amplitude } \\
\text { (minimum - maximum) }\end{array}$ \\
\hline Affective relationships & $3.1(0.8)$ & 0.9 & 4.0 \\
Sexual activity & $2.3(0.1)$ & 0.2 & 3.9 \\
Physical and social adversities & $1.7(1.2)$ & 0.0 & 4.0 \\
\hline
\end{tabular}

\section{DISCUSSION}

There was a predominance of females, as in another study ${ }^{(28)}$ carried out in the same outpatient clinic, the location of this present study. This result portrays the feminization of old age ${ }^{(29)}$. Most participants were married, since one of the inclusion criteria established in this study was to be married or to have a fixed partner. In contrast, in a previous study ${ }^{(28)}$, widowhood was the most common marital status among participants.

In this study, most older adults lived only with their partner, which is a common condition among older adults ${ }^{(29)}$; however, in studies with particular characteristics outlined among the participants, different family arrangements are observed ${ }^{(30)}$. A study on the perception of older adults and family caregivers regarding the aging process, all older adults interviewed lived with the family caregiver ${ }^{(31)}$, being a very common condition among older adults with some degree of dependence, especially those older adults.

As for the health condition, in this study, the most mentioned health problems were high blood pressure and diabetes, being two chronic diseases highly prevalent with population aging. In a study on multimorbidity in people aged 50 or over, using ELSI-Brazil (Longitudinal Health Study of Older Adults in Brazil), conducted with a representative sample in 70 municipalities in the five macro-regions of Brazil, an increase was found the number of morbidities according to age; $17.7 \%$ of participants aged $50-59$ years had no morbidity; in contrast, only $2.7 \%$ of participants aged 80 or over. Systemic Arterial Hypertension was reported by $52.2 \%$, and diabetes mellitus (DM), by $15.8 \%$ of participants, with an average of associated morbidities between 3.5 and 4.2, respectively ${ }^{(32)}$. It is important to note that the presence of chronic diseases can negatively influence the quality of life of older adults, especially in their physical aspects. This fact was observed in patients with DM when compared to the general population ${ }^{(33)}$.

As already mentioned, the intensity of physical and psychological symptoms, reported by the older adults in the present study, was measured using the ESAS- $\mathrm{Br}^{(23)}$ scale, noting that, for all symptoms, older adults reported some degree of intensity. Thus, these symptoms are present in older adults with any clinical condition. In this study, although below the scores that limit the intensity of symptoms by $50 \%$, higher averages were observed, i.e., greater intensity reported for the symptoms of pain, anxiety, drowsiness and feeling of well-being. In a study carried out with

Table 4 - Distribution of correlations between the Edmonton Symptom Assessment Scale and the Affective and Sexual Experiences Scale for Elderly according to symptoms and dimensions, Ribeirão Preto, São Paulo, Brazil, 2019

\begin{tabular}{|c|c|c|c|c|c|c|}
\hline \multirow{3}{*}{$\begin{array}{l}\text { Variables } \\
\text { Edmonton Symptom Assessment } \\
\text { Scale symptoms }\end{array}$} & \multicolumn{6}{|c|}{ Affective and Sexual Experiences Scale for Elderly dimensions } \\
\hline & \multicolumn{2}{|c|}{ Sexual activity } & \multicolumn{2}{|c|}{ Affective relationships } & \multicolumn{2}{|c|}{ Physical and social adversity } \\
\hline & $\mathbf{r}_{s}^{*}$ & $p$ value & $r_{s}^{*}$ & $p$ value & $r_{s}^{*}$ & $p$ value \\
\hline Pain & 0.091 & 0.551 & 0.127 & 0.406 & 0.187 & 0.220 \\
\hline Tiredness & -0.075 & 0.625 & 0.007 & 0.966 & 0.180 & 0.237 \\
\hline Nausea & -0.157 & 0.303 & -0.130 & 0.394 & 0.148 & 0.332 \\
\hline Sadness & -0.365 & $0.014^{* *}$ & -0.386 & $0.009 * *$ & 0.017 & 0.914 \\
\hline Anxiety & -0.308 & $0.040 * *$ & -0.222 & 0.143 & -0.063 & 0.683 \\
\hline Drowsiness & -0.022 & 0.884 & 0.005 & 0.972 & 0.064 & 0.674 \\
\hline Appetite & 0.016 & 0.919 & -0.066 & 0.669 & 0.202 & 0.184 \\
\hline Feeling of well-being & -0.217 & 0.152 & -0.250 & 0.097 & 0.182 & 0.231 \\
\hline Shortness of breath & -0.129 & 0.399 & -0.150 & 0.327 & 0.372 & $0.012 * *$ \\
\hline Sleepiness & -0.053 & 0.728 & -0.248 & 0.100 & 0.001 & 0.997 \\
\hline
\end{tabular}

Note: ${ }^{*} r_{s}=$ Spearman's correlation coefficient. ${ }^{* *}$ statistically significant correlation ( $p$ value $\left.\leq 0.05\right)$. 
older adults in palliative care, the symptoms that presented the highest averages were anxiety (6.09) and pain (5.42). Despite this, $75.76 \%$ of older adults reported "good" quality of life(26).

It is worth mentioning that pain can cause stress and suffering of older adults, and its consequences also involve members of their social circle, especially their family members and caregivers; furthermore, it can generate social, economic and emotional changes ${ }^{(26)}$. Still, it is worth mentioning that pain can influence sexuality of older adults, as revealed in a study ${ }^{(34)}$ with 32 elderly women with chronic pain (lasting six months or more), with the majority $(71.9 \%)$ had pain related to osteoarthritis. The authors of that study ${ }^{(34)}$ highlighted that $28.1 \%$ of the elderly women reported that pain influenced their sexual activity (masturbation, excitation and/or penetration), $81.3 \%$ mentioned the absence of such activity in the last month and $78 \%$ had sexual dysfunction.

Anxiety can lead to social restriction of adults and interfere with their well-being and quality of life, as well as in the performance of activities of daily living ${ }^{(35)}$. Results of a study on the description of symptoms of anxiety and depression in institutionalized older adults in the interior of Bahia, Brazil, showed that anxiety is considered common in this population; for this reason, anxiety symptoms are often underestimated and little explored when referring to studies. Despite this, they are considered negative symptoms that interfere in the life of adults who feel it, resulting in discomfort ${ }^{(36)}$.

It is noteworthy that, in this study, there were negative correlations between the intensity of psychological symptoms (sadness and anxiety) and the affective and sexual experiences of older adults. Therefore, as the intensity of the sadness symptom increases, the scores of ASESE sexual activities and affective relationships dimensions decrease. For the anxiety symptom, as its intensity increases, the mean score of the ASESE sexual act dimension decreases.

As for the physical symptoms assessed by ESAS-Br, in this study, there was a positive correlation between the symptom of shortness of breath and physical and social adversity dimensions of ASESE, showing that the greater the intensity of shortness of breath, the higher the score of that dimension, i.e., older adults who reported greater intensity of this symptom reported higher frequencies in the statements belonging to the physical and social adversities dimension ("some health problems affect my sexual experiences", "I feel uncomfortable due to changes in my sexuality caused by aging" and "I am afraid of being a victim of prejudice because of my attitudes towards sexuality"). It is worth mentioning that the present study assumes a pioneering status in investigating such relationships and, therefore, the results could not be compared with other studies.

In this study, ASESE affective relationships and sexual activity dimensions had the highest averages, which corroborates the results of a study of construction and validation of this scale in Brazil. Therefore, it can be inferred that, for older adults, sexual activity is not a priority in their lives, with emphasis on feelings and emotions prevailing ${ }^{(22)}$.

A sexuality in old age, as well as in other stages of life, can be responsible for several benefits for the person's life, such as increased self-esteem, improved sleep quality, physical exercise, greater brain activity and good humor. Furthermore, the experience of sexuality promotes the release of hormones that prevent depression $^{(37)}$.

As described in literature, in a study conducted with the Portuguese population, sexual activity was significantly associated with the quality of life of the participants in the dimensions of physical function, physical performance and health in general, in addition to some other dimensions that varied from according to the sex of the participants. Thus, sexuality can be considered relevant to people's health and quality of life ${ }^{(38)}$.

Considering the dimensions that involve sexuality (sexual activity, behavioral, affective and cultural aspects) and its relationship with physical and psychological health conditions, it is necessary for health professionals to approach and work with this theme with older adults. It is added that in the presence of a positive perspective of sexual experiences (physical attraction, sexual pleasure, care and mutual support with a partner, companionship, affection, intimacy), older adults have better performance in self-efficacy behavior in health, willingness to well-being and good humor, as well as positive affection in their social relationships and quality of life ${ }^{(39)}$.

In this sense, it is of fundamental importance that health professionals identify the relevant aspects of sexuality to be worked with older adults and assist them in resolving the respective identified needs. Therefore, it is necessary that these professionals, especially nurses, are trained and have technical scientific knowledge regarding the theme of sexuality and also establish a relationship of trust with older adults so that they feel comfortable to report intimate issues. concerning their sexuality ${ }^{(40)}$.

Additionally, it is essential that health professionals develop mechanisms and strategies to conduct and manage communication with older adults using appropriate and easy to understand language, as well as exercise the ability to listen to the prior sexual history of adults and their sexual complaints with empathetic and non-judgmental.

\section{Study limitations}

The results of this study reflect a local reality, so generalizations should be viewed with caution, in order to avoid misunderstandings. It is noteworthy that the data collection performed in just one clinic, as well as the high number of older adults without a fixed partner ( $n=142)$, can be considered a relevant factor for the restriction of the sample size.

This study was a pioneer in investigating correlations between affective and sexual experiences and the intensity of physical and psychological symptoms of older adults. Therefore, despite the scarcity of scientific literature to discuss the results of this study, it is necessary to consider their clinical relevance in relation to affective and sexual experiences and the intensity of physical and psychological symptoms of older adults.

\section{Contributions to nursing and health}

The outcomes of sexuality experiences in old age have been related to more positive behaviors in view of the common limitations of aging. Thus, this study, when addressing this theme, seeks to highlight dimensions of sexuality that may be relevant 
to the care with physical and psychological health, maintaining well-being, good quality of life and social relationships.

There was a prevalence of symptoms of sadness and anxiety and a negative correlation between the affective and sexual experiences of older adults. In this sense, health professionals, when assisting older adults, after establishing a bond and good communication, need to explore and discuss aspects of sexuality (sexual activity, affective relationships, relationship with partners and behavioral attitudes) in together with general health care.

Still, it is important to mention that sexual satisfaction, combined with self-esteem, can improve sexual, mental and physical health. Thus, for there to be a positive sexuality, it is necessary to recognize and value the sexual experiences. Health education actions can be relevant strategies to help improve social relationships through the inclusion of information and instructions on how to achieve a positive sex life, including sexual communication, understanding of physiological factors and self-confidence.
Understanding this context and the meaning of older adults'sexual and affective experiences can allow health professionals to delve into the main resources available to assist in this process, with a view to promoting adult health and healthy aging. These professionals, when reflecting on the inclusion of the theme of sexuality in their daily work, may avoid that there is a gap in the adult care process.

\section{CONCLUSION}

ASESE affective relationships dimension had a higher mean score, i.e., it was mentioned more frequently by the older adults in the study. It is possible to state that, as the intensity of the sadness symptom reported by older adults increases, their affective and sexual experiences are less; the greater the intensity of the anxiety symptom, the lower their sexual experiences and the greater the intensity of the symptom shortness of breath, the greater are the physical and social adversities reported by older adults.

\section{REFERENCES}

1. Rozendo A, Alves J. Sexualidade na terceira idade: tabus e realidade. Rev Kairós: Gerontol. 2015;18(3):95-107. https://doi. org/10.23925/2176-901X.2015v18i3p95-107

2. Gewirtz-Meydan A, Hafford-Letchfield T, Benyamini Y, Phelan A, Jackson J, Ayalon L. Ageism and sexuality. In: Ayalon L, Tesch-Römer C. Contemporary perspectives on ageism [Internet]. Springer, Cham: Int Perspect Aging. 2018:149-62. https://doi.org/10.1007/978-3-319-73820-8_10

3. Sinković M, Towler L. Sexual aging: a systematic review of qualitative research on the sexuality and sexual health of older adults. Qual Health Res. 2018;29:1239-54. https://doi.org/10.1177/1049732318819834

4. Pereira FM, Pottes FA, Cavalcante E, Pinheiro E, Andrade K. La percepción sobre el ejercicio de la sexualidad en ancianos atendidos en el Centro de Salud del Anciano de Recife, Brasil. Rev Enferm Herediana [Internet]. 2008 [cited 2020 Aug 02];1 (2):93-103. Available from: https:// faenf.cayetano.edu.pe/images/pdf/Revistas/2008/febrero/Percepcion_sobre_el_ejercicio_de_la_sexualidad.pdf

5. Coelho DNP, Danter DV, Santana RF, Santo FHE. Percepção de mulheres idosas sobre sexualidade: implicações de gênero e no cuidado de enfermagem. Rev Rene [Internet]. 2010 [cited 2020 Aug 02];11(4):163-73. Available from: http://www.periodicos.ufc.br/rene/article/ view/4641/3466 Portuguese.

6. Grandim CVC, Sousa AMM, Lobo JM. A prática sexual e o envelhecimento. Cogitare Enferm. 2007;12(2):204-213. https://doi.org/10.5380/ce.v12i2.9826

7. Silva RMO. A sexualidade no envelhecer: um estudo com idosos em reabilitação. Acta Fisiátrica [Internet]. 2003 [cited 2020 Aug 02];10(3):107-12. Available from: https://www.revistas.usp.br/actafisiatrica/article/view/102454/100765

8. Martínez VTP, Chávez NA. Comportaminento de la sexualidad en ancianos Del Policlinico "Ana Betancourt". Rev Cubana Med Gen Integr [Internet]. 2008 [cited 2020 Aug 02];24(2):1-9. Available from: http://scielo.sld.cu/pdf/mgi/v24n2/mgi03208.pdf

9. Hernández MM, Díaz PR, Llerenas ES. Estudios clínicos y autopercepcíon de la sexualidad em ancianos com enfoque de género. Rev Cubana Enferm[Internet]. 2009 [cited 2020 Aug 02];25(1-2):1-9. Available from: http://scielo.sld.cu/pdf/enf/v25n1-2/enf031_209.pdf

10. Ferreira KS, Silva MG, Cherem TMDA, Araújo CLO. Percepção dos idosos perante o sexo na idade avançada. Geriatr Gerontol [Internet]. 2009 [cited 2020 Aug 02];3(4):182-88. Available from: https://cdn.publisher.gn1.link/ggaging.com/pdf/v3n4a07.pdf

11. Lenardt MH, Hammerschmidt KSA, Willig MH, Seima MD, Araújo CR. Conception of being elderly by Boca Maldita Gentlemen: a qualitative descriptive study. O Braz J Nurs. 2009;8(3). https://doi.org/10.5935/1676-4285.20092460

12. Hernández MF, Cano MNG, Gonzaléz FM, Calvo IM, Torres EC, Ferrer MEF. Sexualidad en las mujeres mayores. Atenc Primaria. 2006;37(9):5049. https://doi.org/10.1157/13089099

13. Polizer AA, Alves TMB. Perfil da satisfação e função sexual de mulheres idosas. Fisioter Mov [Internet]. 2009 [cited 2020 Aug 02];22(2):151-8. Available from: https://periodicos.pucpr.br/index.php/fisio/article/view/19387/18735

14. World Health Organization (WHO). Sexual Health, human rights and the law [Internet]. 2015 [cited 2018 Apr 13]. Geneva: WHO; Available from: https://apps.who.int/iris/bitstream/handle/10665/175556/9789241564984_eng.pdf;jsessionid=7DC1D3CAD9C85477CC9007DBF3A779D6?se quence $=1$

15. Bezerra A, Carvalho CF, Castro JR, Nascimento AC. A sexualidade e qualidade de vida dos idosos da rede crescer - conviver de Uberlândia. E-rac [Internet]. 2016 [cited 2018 Apr 14];6(1). Available from: http://www.computacao.unitri.edu.br/erac/index.php/e-rac/article/view/705

16. Ministério da Saúde (BR). Caderno de Atenção Básica: envelhecimento e saúde da pessoa idosa [Internet]. 2006 [cited 2020 Aug 03]. Available from: http://bvsms.saude.gov.br/bvs/publicacoes/abcad19.pdf Portuguese. 
17. Vieira KFL, Coutinho MPL, Saraiva ERA. A sexualidade na velhice: representações sociais de idosos frequentadores de um grupo de convivência. Psicol Ciênc Prof. 2016;36(1):196-209. https://doi.org/101590/1982-3703002392013

18. Cesnik VM, Zerbini T. Sexuality education for health professionals: a literature review. Estud Psicol. 2017;34(1):161-72. https://doi. org/10.1590/1982-02752017000100016

19. Silva LM. Comparação de três instrumentos para avaliação da fadiga em pacientes com insuficiência cardíaca [Dissertação]. Universidade de São Paulo, Escola de Enfermagem de Ribeirão Preto; 2016. https://doi.org/10.11606/D.22.2017.tde-26012017-103129

20. Stackfleth R. Adaptação e validação da versão em português da escala Partners in Health (PIH) para a população brasileira com doenças crônicas [Dissertação]. Universidade de São Paulo, Escola de Enfermagem de Ribeirão Preto; 2017. https://doi.org/10.11606/D.22.2018.tde-28112017-160924

21. Pilger C, Menon MH, Mathias TAF. Socio-demographic and health characteristics of elderly individuals: support for health services. Rev Latino-Am Enfermagem. 2011;19(5). https://doi.org/10.1590/S0104-11692011000500022

22. Vieira FLK. Sexualidade e Qualidade de vida do idoso: Desafios contemporâneos e repercussões psicossociais [Tese]. Universidade Federal da Paraíba; 2012. Available from: https://repositorio.ufpb.br/jspui/handle/tede/6908

23. Paiva CE, Manfredini LL, Paiva BS, Hui D, Bruera E. The Brazilian Version of the Edmonton Symptom Assessment System (ESAS) Is a Feasible, Valid and Reliable Instrument for the Measurement of Symptoms in Advanced Cancer Patients. PLoS One. 2015;10(7). https://doi.org/10.1371/ journal.pone. 0132073

24. Lenhani BE, Mercês NNA. Evaluation of symptoms of a patient with bladder cancer receiving palliative care: a case study. Cogitare Enferm. 2017;22(4). https://doi.org/10.5380/ce.v22i4.49867

25. Oliveira ATR. Envelhecimento populacional e políticas públicas: desafios para o Brasil no século XXI. Rev Bras Geogr Econ: Espaço Econ. 2016;(8). https://doi.org/10.4000/espacoeconomia.2140

26. Faller JW, Zilly A, Moura CB, Brusnicki PH. Multidimensional pain and symptom assessment scale for elderly people in palliative care. Cogitare Enferm [Internet]. 2016 [cited 2019 Nov 30];21 (2):01-10. Available from: http://docs.bvsalud.org/biblioref/2016/07/681/45734-182071-1-pb.pdf

27. Bruera E, Kuehn N, Miller MJ. The Edmonton Symptom Assessment System (ESAS): a simple method for the assessment of palliative care patients. J Palliat Care [Internet]. 1991 [cited 2018 May 05];7:6-9. Available from: https://pubmed.ncbi.nlm.nih.gov/1714502/

28. Lima GS, Souza IMO, Storti LB, Silva MMJ, Kusumota L, Marques S. Resilience, quality of life and symptoms of depression among elderlies receiving outpatient care. Rev Latino-Am Enfermagem. 2019;27. https://doi.org/10.1590/1518-8345.3133.3212

29. Sousa NFS, Lima MG, Cesar CLG, Barros MBA. Active aging: prevalence and gender and age differences in a population-based study. Cad Saúde Pública. 2018;34(11). https://doi.org/10.1590/0102-311x00173317

30. Campos ACV, Ferreira EF, Vargas AMD, Gonçalves LH. Healthy aging profile in octogenarians in Brazil. Rev Latino-Am Enfermagem. 2016;24. https://doi.org/10.1590/1518-8345.0694.2724

31. Colussi E, Pichler NA, Grochot L. Perceptions of the elderly and their relatives about aging. Rev Bras Geriatr Gerontol. 2019;22(1). https://doi. org/10.1590/1981-22562018021.170140

32. Nunes BP, Batista SRR, Andrade FB, Souza Jr PRBS, Lima-Costa MF, Facchini LA. Multimorbidity: the Brazilian Longitudinal Study of Aging (ELSI-Brazil). Rev Saúde Pública. 2018;52(suppl 2):10s. https://doi.org/10.11606/s1518-8787.2018052000637

33. Santos RLB, Campos MR, Flor LS. Fatores associados à qualidade de vida de brasileiros e de diabéticos: evidências de um inquérito de base populacional. Ciênc Saúde Coletiva. 2019;24(3):1007-20. https://doi.org/10.1590/1413-81232018243.09462017

34. Santos AM, Santos FC, Cendoroglo MS. Sexuality and chronic pain in long-lived females: description of interferential factors. Rev Dor. 2015;16(1):48-52. https://doi.org/10.5935/1806-0013.20150010

35. Uchmanowicz I, Gobbens RJJ. The relationship between frailty, anxiety and depression, and health-related quality of life in elderly patients with heart failure. Clin Interv Aging. 2015;10:1595-600. https://doi.org/10.2147/CIA.S90077

36. Gomes JB, Reis LA. Description of symptoms of anxiety and depression of institutionalized elderly in the countryside of the State of Bahia, Brazil. Rev Kairós: Gerontol. 2016;19(1):175-91. https://doi.org/10.23925/2176-901X.2016v19i1p175-191

37. Munaretto GF, Rocha OS, Sobral ACG, Costa TA, Teixeira LAC, Albuquerque AT, et al. Sexualidade em idosos. In: Cação MMP, Catarino EM. Conhecimento Científico na área de geriatria e gerontologia [Internet]. Cap. 6. Ponta Grossa (PR): Editora Atena; 2020; 55-63. https://doi. org/10.22533/at.ed5542023016

38. Cambão M, Sousa L, Santos M, Mimoso S, Correia S, Sobral D. QualiSex: estudo da associação entre a qualidade de vida e a sexualidade nos idosos numa população do Porto. Rev Porto Med Geral Fam. 2019;35(1):12-20. https://doi.org/10.32385/rpmgf.v35i1.11932

39. Rahn A, Bennett C, Jones T, Lykins A. Happily partnered older adults' relationship-enhancing behaviors. Australas J Ageing. 2020;(Suppl.1):30-9. https://doi.org/10.1111/ajag.12731

40. Evangelista AR, Moreira ACA, Freitas CASL, Val DR, Diniz JL, Azevedo SGV. Sexuality in old age: knowledge/attitude of nurses of Family Health Strategy. Rev Esc Enferm USP. 2019;53:e03482. https://doi.org/10.1590/S1980-220X2018018103482 